\title{
Passiv røyking av cannabis - hva skal vi tro?
}

\author{
Sammendrag \\ Bakgrunn. Det spørres ofte om passiv \\ røyking av cannabis kan gi positivt \\ utslag på rusmiddeltester i urin. Nylig \\ var samme problemstilling debattert \\ i mediene i idrettssammenheng. Her \\ gjennomgås medisinsk litteratur for \\ å avklare et problem som er en gjen- \\ ganger både i helsevesen, rettsvesen \\ og idrett.
}

\section{Materiale og metode. Artikkelen er basert på litteratursøk i Medline på søkeordene cannabis, marihuana, marijuana, hashish og passive. Søket ble utført i september 2007 og resul- terte i 70 treff. Relevante artikler ble valgt ut på grunnlag av tittel og sammendrag, og det ble foretatt gjen- nomgang av de relevante artiklenes referanselister.}

Resultater. Sju eksperimentelle studier med humandata ble funnet. I to av studiene der fors $ø$ kspersonene ble eksponert for store mengder cannabisrøyk i små og ikke-ventilerte rom, var påfølgende urinprøver positive på cannabinoider. I forsøkene der cannabisrøyking under mer normale forhold ble studert, var ingen prøver positive mer enn noen få timer etter eksponering, og de målte cannabinoidkonsentrasjonene var svært lave.

Fortolkning. Påvisning av cannabinoider i urin ved bruk av tester med dagens konvensjonelle rapporteringsgrenser må tolkes som uttrykk for aktiv røyking.

\author{
Andreas Austgulen Westin \\ andreas.westin@legemidler.no \\ Avdeling for klinisk farmakologi \\ St. Olavs hospital \\ 7006 Trondheim

\section{Lars Slørdal} \\ Institutt for laboratoriemedisin, \\ barne- og kvinnesykdommer \\ Norges teknisk-naturvitenskaplige universitet \\ og \\ Avdeling for klinisk farmakologi \\ St. Olavs hospital
}

Hvis man ser bort fra alkohol, er cannabis (marihuana og hasjisj/hasj) det hyppigst brukte rusmidlet i Norge (1). Når urinprøver benyttes for å avdekke rusmiddelbruk, er det - som en konsekvens av utbredt bruk og relativt lang påvisningstid - oftest cannabinoider som påvises. Testsituasjonene varierer, og prøvegiver er ikke nødvendigvis mistenkt for å ha inntatt cannabis. Det kan for eksempel dreie seg om testing av et oppstartskull på befalskolen, ansatte på en oljeplattform eller annen bedrift med høye krav til sikkerhet eller utøvere på et idrettsarrangement. Testingen kan også finne sted innenfor mer etablerte kontrollrammer: en bilfører etter en kollisjon, en fengselsinnsatt som opptrer påvirket eller en mor som må dokumentere rusfrihet for å beholde omsorgsrett for sitt barn. Det er innlysende at positive urinprøvesvar i alle disse situasjonene kan ha alvorlige konsekvenser for prøvegiver.

Den viktigste psykoaktive komponenten i hasj og marihuana er delta-9-tetrahydrocannabinol (THC). Rusmiddeltestene som anvendes for å påvise cannabisbruk, påviser dette stoffet og/eller nært beslektede substanser og metabolitter (cannabinoider). I dag er det vanligst å teste urin kun for hovedmetabolitten av THC, tetrahydrocannabinolsyre (delta-9-THC-COOH; THCA).

Av og til står positive prøvesvar i kontrast til prøvegivers påstander om rusfrihet. I noen slike tilfeller kan prøvegiver hevde at positiv prøve skyldes passiv eksponering for cannabisrøyk, for eksempel ved at han/hun har oppholdt seg $i$ et telt der andre røyket cannabis eller på en kafé der det «luktet merkelig», eller at vedkommende har flyttet inn i en leilighet der det tidligere har bodd rusmisbrukere. Fra Storbritannia finnes det eksempler på at straffesaker er blitt vunnet ved at man har prosedert med passiv royking som forklaring på cannabinoidfunn $\mathrm{i}$ urin $(2,3)$. I Norge ble spørsmålet aktualisert etter at en idrettsutøver testet positivt på cannabinoider i urin sommeren 2007. Den umiddelbare forklaringen på den positive prøven - en forklaring som senere ble endret - var passiv røyking (4).

I denne artikkelen presenteres det vi i dag vet om passiv inhalasjon av cannabisrøyk og utslag det kan gi på analyser av cannabinoider i urin.

\section{Materiale og metode}

Artikkelen er basert på et litteratursøk i Medline på søkeordene «cannabis» (all fields) OR «marihuana» (all fields) OR «marijuana» (all fields) OR «hashish» (all fields) AND «passive» (all fields). Søket ble utført i september 2007 og resulterte i 70 treff. Relevante, engelskspråklige artikler ble utvalgt på grunnlag av tittel og sammendrag. 19 artikler ble funnet relevante for denne oversikten. En gjennomgang av referanselister i disse identifiserte ytterligere fire relevante artikler. Totalt ble sju eksperimentelle forsøk med humandata identifisert, og resultatene av disse var fordelt på totalt 13 publikasjoner (tab 1) (2, 5-16), som danner grunnlaget for denne oversikten. I tillegg har forfatterne etter eget kjennskap trukket inn relevante referanser vedrørende påvisning av cannabinoider, og om cannabinoiders farmakokinetikk.

\section{Farmakokinetikk ved røyking}

Delta-9-tetrahydrocannabinol blir vanligvis inntatt ved at hasj eller marihuana blandes med tobakk, rulles i sigaretter (joints) og røykes. Når cannabisrøyk inhaleres, absorberes dette stoffet raskt fra røyken, og konsentrasjonsprofilen i blodet (fig 1) likner den man ser ved intravenøs administrasjon (17, 18). Stoffet har høy fettløselighet og et stort tilsynelatende distribusjonsvolum, hvilket forklarer hvorfor konsentrasjonene i blod faller raskt de første timene etter et inntak (19). Etter et enkeltinntak vil $80-90 \%$ av det som er inntatt, bli utskilt i løpet av 4-5 dager, hovedsaklig som fritt eller glukuronidert THC-syre $(17,20)$. På grunn av lang-

\section{Hovedbudskap}

- Cannabinoider i urin er et tegn på at man har vært eksponert for cannabisrøyk i så stort omfang at man må kunne forventes å være klar over det 
som utskilling fra fettvev og en betydelig grad av enterohepatisk sirkulasjon er den terminale halveringstiden for THC og THCsyre i serum lang, henholdsvis 1-2 døgn og 1-3 døgn (17). Tilsvarende halveringstid er også vist for THC-syre i urin (21). Den komplekse farmakokinetikken er godt beskrevet andre steder $(17,18)$, og har nylig også vært tema $\mathrm{i}$ en oversiktsartikkel $\mathrm{i}$ Tidsskriftet (20).

En forutsetning for at passiv røyking av cannabis skal være mulig, er at THC finnes i røyken som går ut i rommet. Det er vist at mange faktorer avgjør mengden av THC i røyken, deriblant måten cannabis røykes på (pipe eller sigarett) og røykerens inhalasjonsteknikk (22). Ved den vanligste formen for cannabisrøyking - i sigaretter - er det anslått at $23-30 \%$ av den totale THC-mengden blir ødelagt ved pyrolyse, ca. 20-37\% trekkes inn av røykeren, mens $40-50 \%$ går ut i rommet (22).

\section{Passiv røyking}

Passiv røyking av cannabis ble første gang beskrevet i 1977 av Zeidenberg og medarbeidere, som gjennom eksponeringsforsøk studerte effektene av langvarig og stort marihuanainntak (23). En ikke-røykende kontrollperson i forsøksrommet ble svimmel og takykard og avla urinprøver der det ble påvist cannabinoidkonsentrasjoner så høye som $260 \mathrm{ng} / \mathrm{ml}$ (24). Konsentrasjoner i denne størrelsesordenen forbindes vanligvis med aktivt inntak (fig 2). Zeidenberg-studien, sammen med mange anekdotiske beskrivelser av rusopplevelse etter passiv røyking (contact highs), motiverte til kontrollerte eksperimentelle forsøk med passiv eksponering for cannabisrøyk. Disse kom på løpende bånd gjennom 1980- og tidlig 90-årene (2, $5-14)$, og to er av nyere dato $(15,16)$. En oversikt over studiene og hovedfunnene er vist i tabell 1.

I de tidligste studiene ble de eksperimentelle forholdene gjort mest mulig lik den naturlige situasjonen for cannabisrøyking. Perez-Reyes og medarbeidere lot to ikkerøykere eksponeres passivt for røyken fra åtte marihuanasigaretter, først i et lite rom, deretter $i$ en stasjonsvogn og til slutt $i$ et lite rom med gjentatt eksponering over tre påfølgende dager (5-8). 74 av de totalt 76 urinprøvene som ble tatt av ikke-røykerne det første døgnet etter eksponering var negative for cannabinoider. To prøver var positive, begge bare så vidt høyere enn analysemetodens rapporteringsgrense på $20 \mathrm{ng} / \mathrm{ml}$. Forfatterne konkluderte med at konsentrasjoner av cannabinoider i urin over $50 \mathrm{ng} / \mathrm{ml}$ som resultat av passiv røyking var umulig, eller i beste fall svært tvilsomt $(5,8)$. Forfatterne påpekte også en rekke metodologiske svakheter ved Zeidenberg-studien (25).

En tilsvarende studie ble gjennomført omtrent på samme tid av Law og medarbeidere (2). I et lite kontor uten ventilasjon ble fire personer eksponert for røyk fra seks mari-

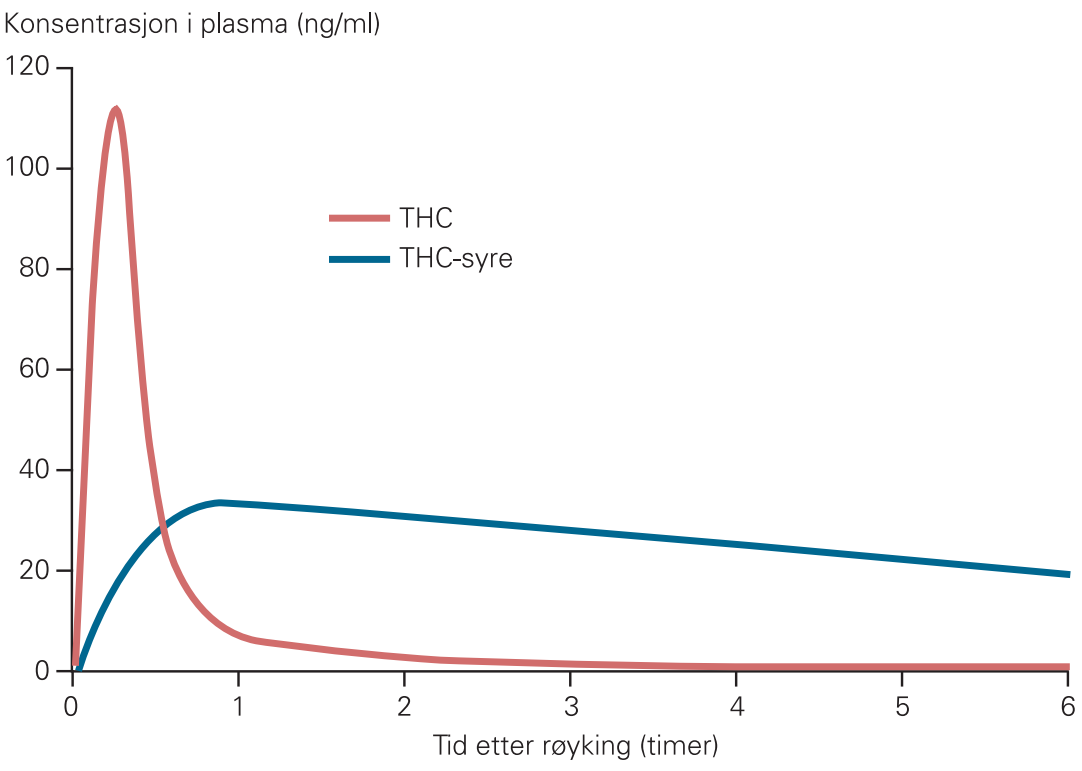

Figur 1 Prinsippskisse av konsentrasjonsprofilene av delta-9-tetrahydrocannabinol (THC) og THC-syre i blod etter røyking av én marihuanasigarett. Forenklet på grunnlag av Grotenhermen (17) og McGilveray (18). Maksimalkonsentrasjon av THC i plasma etter eksponering varierer typisk fra $50-200 \mathrm{ng} / \mathrm{ml}$ etter enkeltinntak ved røyking

huanasigaretter. I dette forsøket ble det påvist cannabinoider i urinen hos alle de passive røykerne, men i svært lave konsentrasjoner $(\leq 7 \mathrm{ng} / \mathrm{ml})(2)$.

Den første studien som påviste høye konsentrasjoner av cannabinoider $\mathrm{i}$ urin etter passiv eksponering, foregikk i Norge. Jørg
Mørland og medarbeidere utførte to forsøk med passiv eksponering under mer ekstreme forhold enn det som tidligere var beskrevet. I et av disse satt fem personer inne $i$ en liten bil mens to av dem røyket til sammen 12 marihuanasigaretter. Røykingen skjedde i løpet av 30 minutter, og røykerne var instruert

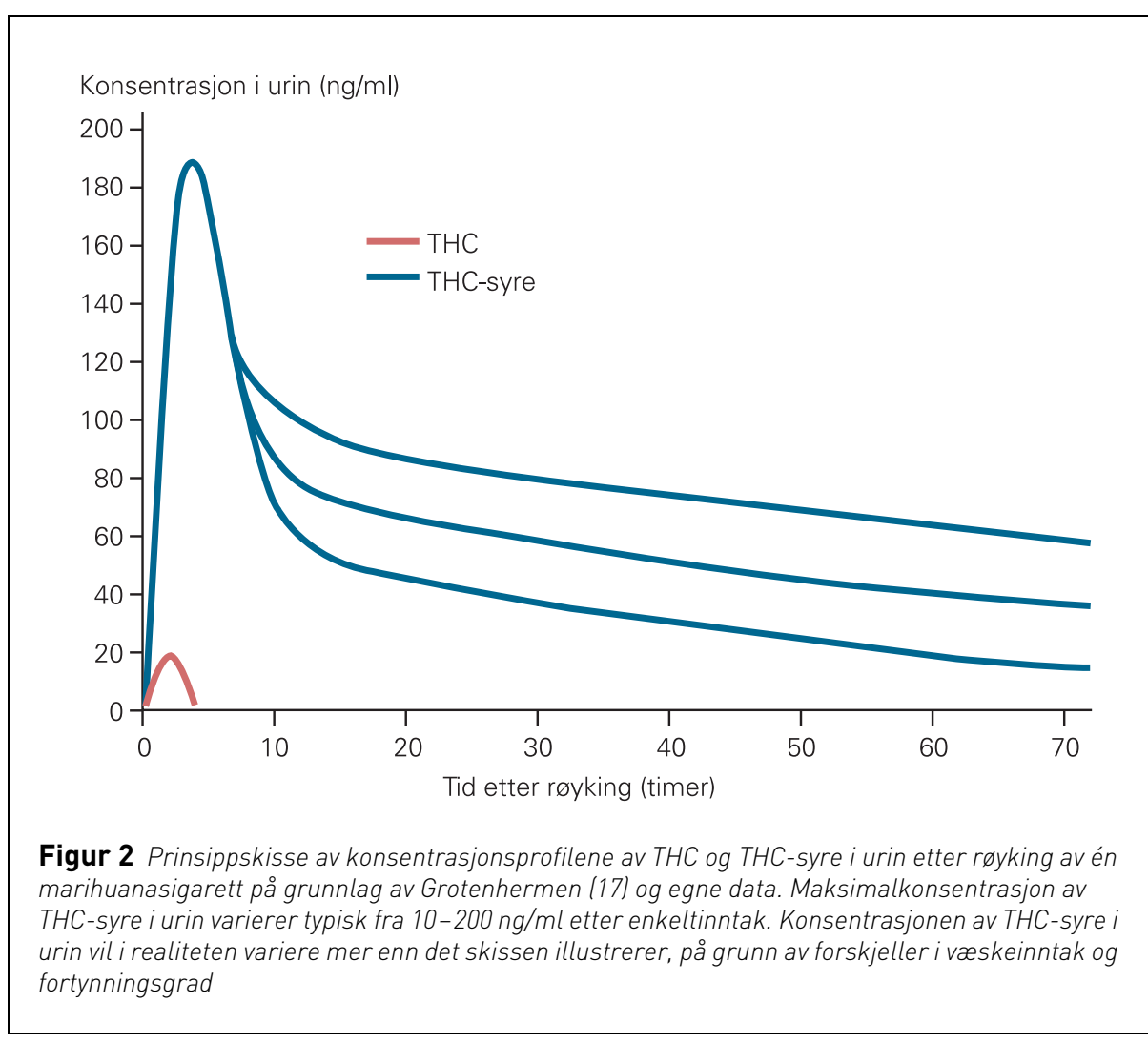


i ikke å inhalere røyken, men å la mest mulig gå ut i rommet. Etter forsøket ble det påvist cannabinoider i ikke-røykernes urin i konsentrasjoner opptil $30 \mathrm{ng} / \mathrm{ml}$. En av forsøkspersonene hadde også konsentrasjoner over rapporteringsgrensen på $13 \mathrm{ng} / \mathrm{ml}$ inntil tre dager senere (9). At passiv røyking av cannabis kan medføre positivt utslag på urinprøver, ble senere bekreftet $\mathrm{i}$ en amerikansk studie også denne med nokså ekstreme betingelser (10-13). Cone og medarbeidere lot fem menn eksponeres passivt en time hver dag $\mathrm{i}$ seks påfølgende dager. Hver eksponering besto av røyk fra 16 marihuanasigaretter, inneholdende til sammen nesten $400 \mathrm{mg}$ THC. Man fant at ikke-røykerne under disse forholdene produserte like mye cannabinoider i urin som de som aktivt hadde royket en eller to marihuanasigaretter (konsentrasjoner i størrelsesorden 80-100 ng/ml). De hadde dessuten atferdsmessige effekter som hos aktive røykere (10-13).

Tre studier (14-16) er publisert etter Cone-studien, de to siste fra 2004 og 2005. Alle disse bekrefter det de tidligste studiene av passiv eksponering viste: Cannabinoider kan påvises i urinen til de passive røykerne, men i svært lave konsentrasjoner ved cannabisrøyking under «normale» betingelser (røyking av ca. fire sigaretter i et lite rom) (14-16). I de to nyeste studiene analyserte man urin både med immunologisk metode (uspesifikk påvisning av cannabinoider) og med gasskromatografisk teknikk, som i dag er referansemetoden. Ingen av de passivt eksponerte hadde urinkonsentrasjoner som overskred analysenes rapporteringsgrenser på henholdsvis $50 \mathrm{ng} / \mathrm{ml}$ og $15 \mathrm{ng} / \mathrm{ml}$. Hos samtlige aktive røykere ble det målt konsentrasjoner over disse grensene (16).

\section{Mange faktorer avgjør}

I de eksperimentelle forsøkene og i diskusjonene og oversiktsartiklene $(19,26)$ som har fulgt i kjølvannet av dem, konkluderes det med at en rekke faktorer vil være avgjørende for hvorvidt, og eventuelt i hvilken konsentrasjon, man kan påvise cannabinoider i urin hos passivt eksponerte. Av helt avgjørende betydning er konsentrasjonen av THC i luften. Konsentrasjonen i luft vil igjen stå i forhold til mengden THC som frigis, det vil si antall sigaretter, THC-mengde $\mathrm{i}$ hver sigarett og røykerens inhalasjonsmønster. Konsentrasjonen i luften vil også være avhengig av luftvolumet røyken fordeler seg i, altså romstørrelsen. I studiene der det er på-

Tabell 1 Oversikt over urinanalyser i eksperimentelle studier av passiv eksponering for cannabisrøyk. Ulike analysemetoder er brukt for påvisning av cannabinoider i urin: EMIT (enzyme multiplied immunassay technique) og RIA (radioimmunoassay) er henholdsvis enzymkoblede og radioaktive immunologiske metoder. Disse metodenes sensitivitet for ulike cannabinoider kan variere og giør at testresultater mellom ulike metoder ikke nødvendigvis er sammenliknbare. Kromatografiske metoder (som GC/MS) tillater derimot nøyaktig kvantitering av hovedmetabolitten THC-syre. $\mathrm{n} / \mathrm{a}=\mathrm{ikke}$ angitt

\begin{tabular}{|c|c|c|c|c|c|c|c|c|}
\hline Fors $ø$ ksrom (luftvolum i liter) & $\begin{array}{c}\text { Antall } \\
\text { sigaretter (es- } \\
\text { timert THC- } \\
\text { mengde) } \\
\text { (mg) }\end{array}$ & $\begin{array}{l}\text { Tid } \\
\text { (min) }\end{array}$ & $\begin{array}{c}\text { Ant. } \\
\text { passive } \\
\text { røykere }\end{array}$ & $\begin{array}{c}\text { Analyse } \\
\text { (rapporterings- } \\
\text { grense } \\
\text { ing/ml) }\end{array}$ & $\begin{array}{c}\text { Positive } \\
\text { urinprøver/ } \\
\text { totalt antall } \\
\text { prøver første } \\
\text { døgn }\end{array}$ & $\begin{array}{l}\text { Maksimal } \\
\text { påvisningstid/ } \\
\text { total over- } \\
\text { våkingstid } \\
\text { i timer }\end{array}$ & $\begin{array}{c}\text { Høyeste påviste } \\
\text { konsentrasjon } \\
n g / m l \\
\text { (timer etter } \\
\text { eksponering) }\end{array}$ & (Referanse) \\
\hline Lite, uventilert rom (27 950) & $6^{2}(103)$ & $\begin{array}{l}\text { Opptil } \\
180\end{array}$ & 4 & RIA (2) & $9 / 16$ & $6 / 8$ & $6,8(6)$ & (2) \\
\hline Lite rom (15 500) & $8(46)$ & 60 & 2 & EMIT (20) & $0 / 15$ & $0 / 24$ & Ikke påvist & $(5-8)$ \\
\hline Lite rom (15 500) & 8 (52) & 60 & 2 & EMIT (20) & $0 / 11$ & $0 / 24$ & Ikke påvist & \\
\hline Stor bil (3 500) & $8(52)$ & 60 & 2 & EMIT (20) & $1 / 23$ & $6 / 24$ & $20(6)$ & \\
\hline Lite rom (15 500) & $4^{1}(105)$ & 60 & 2 & EMIT (20) & $1 / 271$ & $5 / 24^{1}$ & $20(5)^{1}$ & \\
\hline Liten bil (1 650) & $6^{2}(90)$ & 30 & 2 & EMIT (20) & $0 / 2$ & $0 / 120$ & Ikke påvist & (9) \\
\hline \multirow[t]{2}{*}{ Liten bil (1 650) } & $12(90)$ & 30 & 3 & EMIT (20) & $3 / 8$ & $48 / 96$ & $>20(0-48)$ & \\
\hline & & & & RIA (13) & $3 / 3$ & $72 / 96$ & $30(24)$ & \\
\hline \multirow[t]{3}{*}{ Lite, uventilert rom (12 226) } & $16^{3}$ (393) & 60 & 5 & EMIT (20) & $\mathrm{n} / \mathrm{a}$ & $57 / 144^{3}$ & $>75(<6)^{3}$ & $(10-13)$ \\
\hline & & & & RIA (10) & $\mathrm{n} / \mathrm{a}$ & $218 / 240^{3}$ & $91(<6)^{3}$ & \\
\hline & & & & GC/MS (5) & $\mathrm{n} / \mathrm{a}$ & $123 / 192^{3}$ & $35(<6)^{3}$ & \\
\hline \multirow[t]{3}{*}{ Lite, uventilert rom (12 226) } & $4^{3}(98)$ & 60 & 5 & EMIT (20) & $\mathrm{n} / \mathrm{a}$ & $7 / 96^{3}$ & $20(<6)^{3}$ & \\
\hline & & & & RIA (10) & $\mathrm{n} / \mathrm{a}$ & $68 / 192^{3}$ & $35(<6)^{3}$ & \\
\hline & & & & GC/MS (5) & $\mathrm{n} / \mathrm{a}$ & $25 / 96^{3}$ & $<10(25)^{3}$ & \\
\hline \multirow[t]{3}{*}{ Lite, uventilert rom (12 226) } & $16^{3}$ (393) & 60 & 2 & EMIT (20) & $\mathrm{n} / \mathrm{a}$ & $141 / 216^{3}$ & $>75(<6)^{3}$ & \\
\hline & & & & RIA (10) & $\mathrm{n} / \mathrm{a}$ & $145 / 192^{3}$ & $>100(0-48)^{3}$ & \\
\hline & & & & GC/MS (5) & $\mathrm{n} / \mathrm{a}$ & $141 / 192^{3}$ & Ca. $70(<6)^{3}$ & \\
\hline Vinduløst rom (21 600) & $4(108)$ & 60 & 3 & RIA (6) & $0 / 3$ & $0 / 24$ & $\begin{array}{l}<6 \mathrm{ng} / \mathrm{ml} \\
(20-24)\end{array}$ & (14) \\
\hline \multirow[t]{2}{*}{ Lite, uventilert rom (36 000) } & $5(64)$ & 20 & 4 & EMIT (50) & $0 / 8$ & $0 / 4$ & Ikke påvist & (15) \\
\hline & & & & GC/MS (15) & $0 / 8^{4}$ & $0 / 4$ & $3,4(4)^{4}$ & \\
\hline \multirow[t]{4}{*}{ Liten buss (15 300) } & $4(158)$ & 60 & 4 & EMIT (50) & $0 / 26$ & $0 / 72$ & Ikke påvist & (16) \\
\hline & & & & GC/MS (15) & $0 / 26^{4}$ & $0 / 72$ & $14,7(6)^{4}$ & \\
\hline & 4 (333) & 60 & 4 & EMIT (50) & $0 / 15$ & $0 / 8$ & Ikke påvist & \\
\hline & & & & GC/MS (15) & $0 / 16^{4}$ & $0 / 8$ & $10,8(6)^{4}$ & \\
\hline
\end{tabular}

${ }^{1}$ Gjentatt eksponering over tre påfølgende dager. Antall sigaretter, THC-mengde etc. gjelder for hver enkelt eksponering. Antall positive prøver gjelder summarisk for hele forsøket. Påvisningstid og høyeste konsentrasjon gjelder etter siste eksponering

${ }^{2}$ Hasj, ikke marihuana

${ }^{3}$ Gjentatt eksponering over seks påfølgende dager. Antall sigaretter, THC-mengde etc. gjelder for hver enkelt eksponering. Påvisningstid og høyeste konsentrasjon gjelder etter siste eksponering

${ }^{4}$ Høyeste målte konsentrasjon var lavere enn analysemetodens rapporteringsgrense 
vist høye cannabinoidkonsentrasjoner i ikkerøykeres urin har eksponeringen vært stor (10-13) og/eller luftvolumet ekstremt lite (9). Dårlig eller ingen ventilasjon i eksponeringsrommet er også en forutsetning. Cone og medarbeidere fant at bare det å la døren til forsøksrommet stå åpen medførte at THC-konsentrasjonen i luften falt til en tidel (11). Videre er tidsaspektet viktig; både tiden man er eksponert og tiden som går fra eksponering til prøvetaking. Cone og medarbeidere viste at selv under de aller mest ekstreme betingelsene der urealistisk mye THC ble passivt inhalert, måtte forsøkspersonene oppholde seg i dette svært røykfulle rommet i minst ti minutter for at påfølgende urinprøver skulle inneholde cannabinoider (11). Når det gjelder prøvetakingstidspunkt, vil de høyeste konsentrasjonene av cannabinoider i urin oppnås de nærmeste timene etter eksponering. Kun i studiene med de mest ekstreme betingelsene har det vært mulig å påvise cannabinoider i urin i mer enn et døgn etter passiv eksponering $(9,11)$.

Valg av analysemetode er også avgjørende, både for om cannabinoider lar seg påvise og for hvilken konsentrasjon som eventuelt påvises. I de tidlige forsøkene er det benyttet immunologiske teknikker for kvantitativ analyse av cannabinoider. Disse metodene har begrenset evne til å bestemme nøyaktige konsentrasjoner og gir ofte kvalitative svar (positiv eller negativ) ut fra en på forhånd definert rapporteringsgrense. Tabell 1 viser hvilke metoder som er brukt i de ulike forsøkene, hvilken rapporteringsgrense som ble benyttet, og hvor mange prøver som ga positivt utslag med disse grensene. I senere tid har kromatografiske metoder (GC/MS og LC/MS) i stor grad erstattet de immunologiske. Disse metodene tillater nøyaktig kvantitering av THC-syre helt ned i lave konsentrasjoner, uten kryssreaksjon med andre cannabinoider. I de to nyeste studiene som anvendte slik metode, klarte man å påvise THC-syre i urin hos ikke-røykerne, men under «normale» forhold i svært lave konsentrasjoner (under $15 \mathrm{ng} / \mathrm{ml}$ ) og kun kort tid etter eksponering $(15,16)$.

\section{Andre testmatriser}

I de eksperimentelle studiene som her er referert, har man hovedsakelig benyttet urin som påvisningsmedium for cannabinoider. Dette skyldes at konsentrasjonene er høyest i urin samt at THCs farmakokinetikk - med kortvarig tilstedeværelse i blod - gjør urin til et mer egnet medium for påvisning (fig 1, fig 2).

I studiene der man også samlet blodprøver etter passiv eksponering for cannabisrøyk, ble THC enten ikke påvist i plasma (2) eller det ble påvist i lave konsentrasjoner (under $6 \mathrm{ng} / \mathrm{ml}$ ) og svært kort tid (0-2 timer) etter eksponering $(8,9)$. Unntaket var studien med ekstrem og gjentatt eksponering, der konsentrasjoner opptil $19 \mathrm{ng} / \mathrm{ml}$ ble målt på siste eksponeringsdag, men ikke dagen etter (18). Det skal altså godt gjøres å identifisere en passiv cannabisrøyker ved hjelp av blodprøver. Eventuell påvisning i blod vil tale sterkt for aktiv røyking i nær tidsmessig tilslutning til prøvetakingen.

Spytt har vært fremholdt som en alternativ - og ikke-invasiv - metode for påvisning av rusmidler. Denne brukes mye blant annet $i$ arbeidslivstesting i USA (27). Munnen som farmakokinetisk kompartment er imidlertid ikke fullt ut forstått, spesielt når det gjelder THC (28). Det kan imidlertid se ut til at konsentrasjonene i spytt gjenspeiler de i serum (29). I tidlige studier fant man lave konsentrasjoner i spytt opptil 30 minutter etter passiv eksponering for cannabisrøyk $(15,30)$. I en nyere studie av samme forfattere konkluderes det med at disse funnene var forårsaket av prøvekontaminasjon og at påvisning $\mathrm{i}$ spytt hos ikke-røykere ved bruk av konvensjonelle rapporteringsgrenser er usannsynlig (16).

Hårtesting er også en høyaktuell metode ikke-invasiv og tilbakeskuende - i forbindelse med rusmiddeltesting. Problemet med håranalyser av cannabinoider er at både THC og THC-syre i svært liten grad inkorporeres i hår sammenliknet med andre rusmidler, som for eksempel kokain (31). Flere tilfeller er beskrevet der cannabinoider er påvist $\mathrm{i}$ urin, men ikke i hår (31). I tillegg kommer problemet med ekstern kontaminasjon på grunn av passiv eksponering for cannabisrøyk. Det finnes imidlertid preanalytiske teknikker som fjerner mye av stoffene $i$ hårstråenes overflate, mens stoffene i hårstammen bevares. Dette gir betydelig redusert risiko for positivt prøvesvar som resultat av passiv eksponering (32).

\section{Diskusjon}

Det er naturlig å se for seg at et rusmiddel som inhaleres i røyk i noen grad kan inhaleres av personer som sitter ved siden av røykere. Den store forskjellen mellom aktiv og passiv røyking ligger i mengden THC som inntas. Mens en aktiv røyker inhalerer konsentrert cannabisrøyk, vil den passivt eksponerte inhalere røyk der THC-mengden er betydelig fortynnet. Konsentrasjonen i luften vil være avhengig av blant annet mengden som røykes, romstørrelse og ventilasjon. Når man i eksperimentelle forsøk har gjort luftvolumet ekstremt lite og THC-mengden som røykes urealistisk høy, er det ikke uventet at man kan demonstrere høye konsentrasjoner av cannabinoider i urin også hos de passivt eksponerte. Dette kan sammenliknes med å lede røyk inn i en lukket beholder og deretter inhalere fra beholderen. I den ene av de to ekstreme studiene ble det beskrevet at røyken i forsøksrommet var så intens at «det nærmet seg grensen av hva det gikk an å holde ut uten intolerabelt ubehag» (9). I den andre ble det brukt briller som beskyttelse mot røyken, og forsøkspersonene uttrykte at uten disse var det usannsynlig at noen ville klare å oppholde seg i rommet over lengre tid (11). Det er kun i disse to studiene det er blitt påvist cannabinoider i urin i konsentrasjoner over konvensjonelle rapporteringsgrenser i flere dager etter at forsøkene var avsluttet $(9,11)$. I studiene der røykingen har foregått under mer realistiske forhold, har det kun vært påvist lave konsentrasjoner av cannabinoider $i$ urin og $i$ ingen av studiene i mer enn et døgn etter eksponering (2, 5, 14-16). Påvisning av cannabinoider i urin etter passiv eksponering er med andre ord, som for aktiv røyking, et spørsmål om dose.

\section{Konklusjon}

På grunnlag av de publiserte studiene kan vi med høy grad av sikkerhet utelukke uvitende passiv røyking som årsak til positive prøver. Man kan neppe utsette seg for passiv røyking under slike forhold som er beskrevet $\mathrm{i}$ de mest ekstreme forsøkene, uten å forstå at det røykes cannabis på stedet.

Resultatene fra de eksperimentelle studiene kan ekstrapoleres til dagens analysepraksis også i Norge. Dagens konvensjonelle rapporteringsgrenser er av samme størrelsesorden som de som er brukt i de eksperimentelle studiene - eller høyere. Påvisning av cannabinoider i urin ved bruk av dagens tester må tolkes som uttrykk for aktiv røyking.

Oppgitte interessekonflikter: Forfatterne er ansatt ved en avdeling som utfører rusmiddelanalyser. Lars Slørdal er medlem av Toksikologisk gruppe, Den rettsmedisinske kommisjon.

\section{Litteratur}

1. SIRUS. Rusmidler i Norge 2006. Oslo: Statens institutt for rusmiddelforsking, 2006: 112-8.

2. Law B, Mason PA, Moffat AC et al. Passive inhalation of cannabis smoke. J Pharm Pharmacol 1984; 36: $578-81$

3. Busuttil A, Obafunwa JO, Bulgin S. Passive inhalation of cannabis smoke: a novel defence strategy? J Clin Forensic Med 1996: 3: 99-104.

Kvamme S. Hvordan kan jeg røyke cannabis og løpe fort? Dagbladet 14.8.2007.

5. Perez-Reyes M, Di Guiseppi S, Mason AP et al. Passive inhalation of marihuana smoke and urinary excretion of cannabinoids. Clin Pharmacol Ther 1983: 34: 36-41.

6. Mason AP, Perez-Reyes M, McBay AJ et al. Cannabinoid concentrations in plasma after passive inhalation of marijuana smoke. J Anal Toxicol 1983: 7: 172-4.

7. Perez-Reyes M, di Guiseppi S, Davis KH. Passive inhalation of marijuana smoke and urinary excretion cannabinoids. JAMA 1983; 249: 475

8. Mason AP. Perez-Reyes M, McBay AJ et al. Cannabinoids in plasma after passive inhalation of marijuana smoke. JAMA 1983; 249: 475-6.

9. Mørland J, Bugge A, Skuterud B et al. Cannabinoids in blood and urine after passive inhalation of Cannabis smoke. J Forensic Sci 1985; 30 : 997-1002.

10. Cone EJ, Johnson RE. Contact highs and urinary cannabinoid excretion after passive exposure to marijuana smoke. Clin Pharmacol Ther 1986; 40: 247-56.

11. Cone EJ, Johnson RE, Darwin WD et al. Passive inhalation of marijuana smoke: urinalysis and room air levels of delta-9-tetrahydrocannabinol. Anal Toxicol 1987: 11: 89-96.

12. Cone EJ, Roache JD, Johnson RE. Effects of passive exposure to marijuana smoke. NIDA Res Monogr 1987; 76: $150-6$

13. Cone EJ. Marijuana effects and urinalysis after passive inhalation and oral ingestion. NIDA Res Monogr 1990; 99: 88-96. 
14. Mule SJ, Lomax P, Gross SJ. Active and realistic passive marijuana exposure tested by three immunoassays and GC/MS in urine. J Anal Toxicol 1988; 12: 113-6

15. Niedbala S, Kardos K, Salamone S et al. Passive cannabis smoke exposure and oral fluid testing. J Anal Toxicol 2004; 28: 546-52.

16. Niedbala RS, Kardos KW, Fritch DF et al. Passive cannabis smoke exposure and oral fluid testing. II. Two studies of extreme cannabis smoke exposure in a motor vehicle. J Anal Toxicol 2005; 29: 607-15.

17. Grotenhermen F. Pharmacokinetics and pharmacodynamics of cannabinoids. Clin Pharmacokinet 2003; 42: 327-60.

18. McGilveray IJ. Pharmacokinetics of cannabinoids. Pain Res Manag 2005; 10: 15-22A.

19. Moffat AC. Monitoring urine for inhaled cannabinoids. Arch Toxicol Suppl 1986; 9: 103-10

20. Khiabani HZ, Mørland J. Cannabis og cannabinoider som legemidler. Tidsskr Nor Lægeforen 2007; 127: 579-82

21. Huestis MA, Cone EJ. Urinary excretion half-life of 11-nor-9-carboxy-delta9-tetrahydrocannabinol in humans. Ther Drug Monit 1998; 20: 570-6.

22. Perez-Reyes M. Marijuana smoking: factors that influence the bioavailability of tetrahydrocannabinol. NIDA Res Monogr 1990; 99: 42-62.

23. Hembree WC, Nahas GG, Zeidenberg $P$ et al. Changes in human spermatozoa associated with high dose marihuana smoking. Adv Biosci 1978; 22-23: 429-39.

24. Zeidenberg P. Bourdon R, Nahas GG. Marijuana intoxication by passive inhalation: documentation by detection of urinary metabolites. Am J Psychiatry 1977; 134: 76-7.

25. Falck R. Passive inhalation of marijuana smoke. JAMA 1983; 250: 898

26. Hayden JW. Passive inhalation of marijuana smoke: a critical review. J Subst Abuse 1991; 3 : 85-90.

27. Cone EJ, Huestis MA. Interpretation of oral fluid tests for drugs of abuse. Ann N Y Acad Sci 2007. 1098: 51-103.

28. Kauert GF, Ramaekers JG, Schneider E et al. Pharmacokinetic properties of delta9-tetrahydrocannabinol in serum and oral fluid. J Anal Toxicol 2007; 31: 288-93.

29. Huestis MA, Cone EJ. Relationship of delta 9-tetrahydrocannabinol concentrations in oral fluid and plasma after controlled administration of smoked cannabis. J Anal Toxicol 2004; 28: 394-9.

30. Niedbala RS, Kardos KW, Fritch DF et al. Detection of marijuana use by oral fluid and urine analysis following single-dose administration of smoked and oral marijuana. J Anal Toxicol 2001; 25: 289-303.

31. Musshoff F, Madea B. Review of biologic matrices (urine, blood, hair) as indicators of recent or ongoing cannabis use. Ther Drug Monit 2006; 28: $155-63$.

32. Tsanaclis L, Wicks JF. Differentiation between drug use and environmental contamination when testing for drugs in hair. Forensic Sci Int 2008; 176: 19-22

Manuskriptet ble mottatt 25.3. 2008 og godkjent 24.9. 2008. Medisinsk redaktør Åslaug Helland. 